\title{
A NEUROLÓGIA HELYZETE ÉS PERSPEKTÍVÁI MAGYARORSZÁGON'
}

\section{THE SITUATION AND PERSPECTIVES OF NEUROLOGY IN HUNGARY}

\author{
Bereczki Dániel ${ }^{*}$, Ajtay András* \\ *az MTA doktora, Semmelweis Egyetem Neurológiai Klinika, Budapest, Egészségügyi Szakmai Kollégium Neurológiai Tagozata \\ bereczki.daniel@med.semmelweis-univ.hu \\ ** tudományos munkatárs, Semmelweis Egyetem Neurológiai Klinika, Budapest
}

\begin{abstract}
ÖSSZEFOGLALÁS
Az elmúlt két évtized során a neurológiai betegellátó kapacitások Magyarországon jelentősen csökkentek. Az ország neurológiai ellátásában nagyok a regionális különbségek. A hagyományos - kutatói kezdeményezésủ - tudományos tevékenység, a PhD-képzés és az MTA doktora fokozatszerzés szinte kizárólag az egyetemi klinikákon zajlik. A kórházakban a gyógyszeripar által kezdeményezett kutatások dominálnak, ebben sokszor hatékonyabban vesznek részt, mint az egyetemi klinikák. A graduális képzésben a neurológia iránti érdeklődés nem kielégítő. A neurológia választása a friss diplomásoknál az egyetemi klinikákon megfelelő, de a kórházi pozíciókra történő jelentkezés - különösen a nagyvárosokon kívül - nem preferált. A rezidensképzés programja országosan egységes, de a tényleges körülményekben nagyok a regionális különbségek. Jellemző a neurológiai szakterületen a túlterheltség, a szakemberhiány. Számottevő az elvándorlás, ez különösen a fiatal és középgenerációt, és a tudományos minősitéssel rendelkezőket érinti. Az elmúlt két évtizedben megfigyelt tendenciák alapján várható a neurológus létszám további csökkenése és az elöregedés. A rendszerben maradásra motiválna a háziorvosi rendszerhez hasonló közfinanszírozott magánellátás bevezetése, a jelenlegi mértékú finanszírozás azonban ehhez nem elegendő.
\end{abstract}

\section{ABSTRACT}

Neurological healthcare capacities have considerably decreased in the last two decades in Hungary. There are large regional differences in the volume of neurological services in the country. The traditional - science-initiated - scientific research, PhD training and efforts to obtain the degree of the Doctor of the Hungarian Academy of Sciences almost exclusively occur at university departments. Hospitals are mostly involved in clinical studies initiated by the pharma industry, and in this field some hospitals are more active and efficient than university departments. In gradual medical education the interest for neurology is not overwhelming. When medical graduates apply for residency positions, the application rate is high for positions at university departments, but the interest is not sufficient regarding hospital positions

${ }^{1}$ A cikk az MTA Orvosi Tudományok Osztálya 2018. január 17-i ülésén elhangzott előadás alapján készült. 
outside the large cities. The program of residency training in neurology is uniform throughout the country, but there are large regional differences in real conditions. Surfeit and lack of human resources are characteristic universally in the field of neurology. Emigration and leaving the field of neurology has been considerable, affecting mainly the young and middle-age generations and those with scientific degree. Based on observed trends in the last two decades we can expect further decrease in the numbers and an increase in the mean age of board certified practicing neurologists. Motivation to stay in the system could be the introduction of publicly financed private practice into the system, however the current level of financing is not sufficient for this purpose.

Kulcsszavak: neurológia, betegellátás, szakorvosi kormegoszlás, tudományos kutatás, helyzetelemzés

Keywords: neurology, patient care, age distribution of neurologists, scientific research, evaluation of current situation

A neurológia a központi idegrendszer, a perifériás idegrendszer és a vázizomzat betegségeinek diagnosztikájával és kezelésével foglalkozó szakterület. A betegellátáson túl a neurológia feladata még a szakterület oktatása a graduális orvosképzésben, a posztgraduális képzés (szakorvosképzés és szakorvosi továbbképzés), valamint a tudományos kutatómunka. A neurológiai ellátás felmérésére 2009-ben és 2012-ben került sor (Bereczki-Ajtay, 2011; Bereczki-Ajtay, 2012; Majláth et al., 2013). A neurológiai betegségek országos terhének elemzése jelenleg folyik (Oberfrank et al., 2018). Közleményünkben kitérünk a neurológiai szakellátás szervezeti változásaira (ágyszámok a fekvőbeteg-ellátásban, heti szakorvosi óraszámok a járóbeteg-ellátásban); a szakorvosokra (a szakorvosok száma, kormegoszlása, terhelése); az utánpótlás helyzetére (elöregedés, elvándorlás, szakorvosképzés); a jelen kihívásaira az ellátásszervezés, a betegellátás, az oktatás és a tudományos munka területein. Összefoglaljuk mind az egyetemi klinikákon, mind a kórházakban előforduló aktuális problémákat. Végül felvetjük a jövő lehetőségeit.

\section{SZERVEZETI VÁLTOZÁSOK AZ ELMÚLT ÉVTIZEDBEN}

A neurológiai ellátásban 2007 jelentős év volt, a 3733 neurológiai kórházi ágy 2812-re csökkent, országosan tizenkét neurológiai osztály szünt meg, négy megyében csak egyetlen kórházi neurológiai osztály maradt. Az ágyszámcsökkenést nem kompenzálta a járóbeteg-ellátás növekedése: a heti neurológiai szakorvosi óraszám a 2004-es 10 025-röl 2009-re 9942-re csökkent. 


\section{A NEUROLÓGUS SZAKORVOSOK}

Magyarországon 55 neurológiai osztály és 185 neurológiai járóbeteg-ellátó egység müködik. 2010-ben az egész országban érvényes müködési nyilvántartással 1310 neurológiai szakorvos rendelkezett, a fövárosi $(\mathrm{n}=477)$ és a fóvároson kívüli $(\mathrm{n}=833)$ neurológiai szakvizsgával és müködési engedéllyel rendelkezők kormegoszlását az 1. ábra foglalja össze. Elsősorban a fővárosi neurológusok életkori megoszlásán látható a szakma elöregedése.

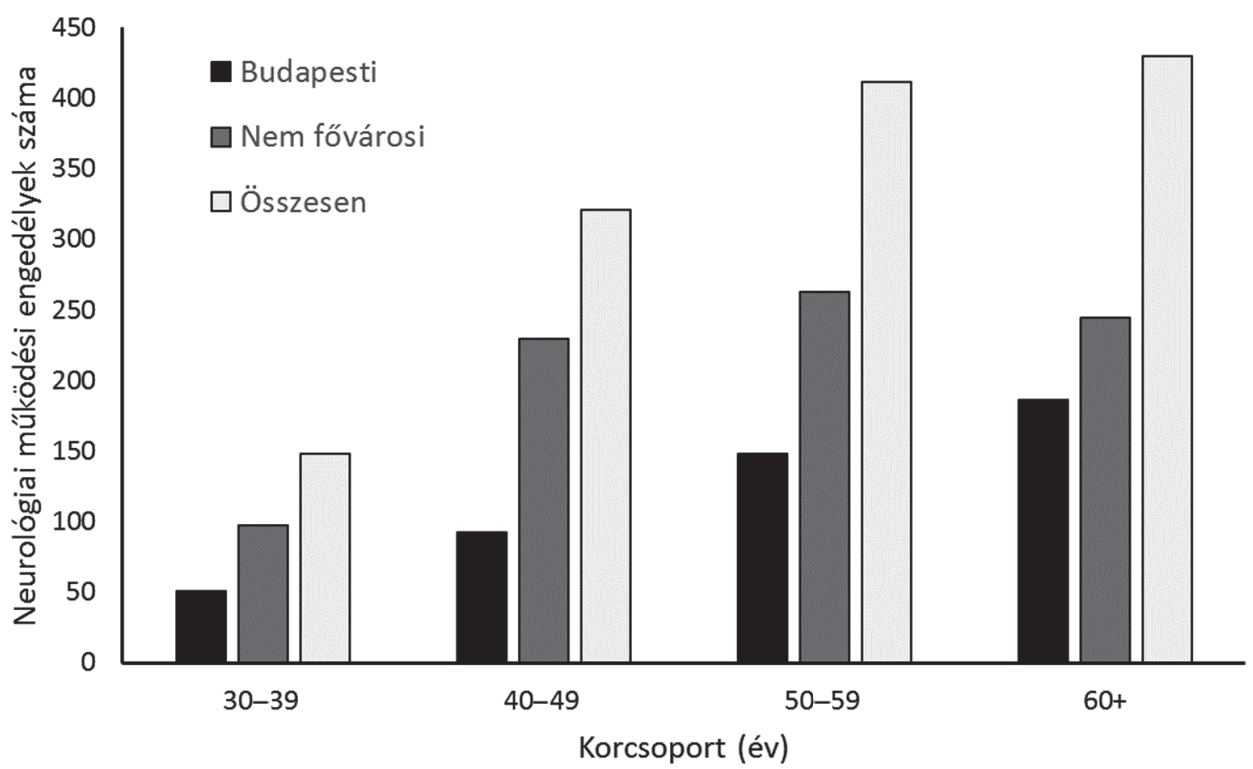

1. ábra. A neurológiai szakorvosi működési engedéllyel rendelkezők kormegoszlása, 2010. március (a szerzők saját szerkesztése)

A szakorvosi ellátottság az egyetemi városokban általában problémamentes, de jellemző a csökkenő létszámú középgeneráció. Az aktív neurológus szakorvosok számának csökkenése miatti jelentős ellátási nehezítettség néhány éven belül várható. A megyei kórházakban régiónként nagy különbségek vannak, a létszám néhány osztályon kilégítő, viszont van olyan kórház, ahol a helyzet kritikus, például 130 kórházi ágyra (és emellett a szakambulanciák és ügyeletek ellátására) összesen kilenc szakorvos áll rendelkezésre. Nagy a fluktuáció: a távozó szakorvosok (külföldre, illetve jobban fizető vagy kevesebb terheléssel járó hazai pozíciókba), a csökkenő számú középgeneráció és a hiányzó fiatal szakorvosi réteg jelzi, hogy a szakorvosi utánpótlással a közeljövőben gondok lesznek. 
Az orvosegyetemek neurológiai klinikáin az ágyszám 55-100 közötti, az ott dolgozó diplomások számában vannak nagy különbségek, ezért a klinikai ügyeletek száma havi négy-öt (nyáron hét-tíz), A klinikai szakorvosokra jellemző a „multitasking” (egy időben ügyeletes, orvostanhallgatók számára gyakorlatot vezet, tutor a szakorvosképzésben, fekvőbeteg osztálya van, és szakrendelésen is beteget lát el).

A kórházi osztályok között nagy különbségek vannak az ágyszámban. Jellemző a nagy betegforgalom, ezzel szemben a feladatokhoz képest alacsony a létszám. A létszám csökkenése fokozódó rutin és ügyeleti terheléssel jár (akár hat ügyelet/hó), a betegvizsgálatokhoz az előjegyzési idő növekszik. A sürgősségi osztályok elindulása óta az ügyeleti időben kért neurológiai konzíliumok iránti igény jelentősen megnőtt - a nehéz ügyeletek miatt a kórházi szakorvosi pozíció egyre kevésbé vonzó. Vannak kifejezetten hátrányos földrajzi területek (például Északkelet-Magyarország). A szükség úgy hozhatja, hogy a neurológiai osztályokról szakorvosi kivezénylések történhetnek ellátatlanná vált területekre, vagy pedig az ellátatlanná vált területek feladatait kell egy-egy osztálynak átvenni.

\section{AZ UTÁNPÓTLÁS HELYZETE}

A 21. században a neurológiai szakvizsgát szerzők számát éves bontásban a 2. ábra foglalja össze. Átlagosan évente huszonhárom fő szerez Magyarországon neurológiából szakképesítést. A rezidensek számát a négy orvosegyetem neurológiai klinikáján megfelelőnek látják. A kórházakban a rezidensek száma változó, általában kicsi az érdeklődés a kórházi pozíciókra. Egyes kisebb osztályoknak a szakorvosképzésre csak részleges jogosultságuk van - tehát a szakképzés egy részét a rezidensnek más intézményben kell eltölteni - emiatt a rezidensek az ilyen munkahelyeket nem szívesen választják. Van olyan kórház, ahol már öt éve nincs rezidens. A nagyobb osztályokon elégséges a rezidensi létszám, de átvezénylések történhetnek (például osztályos munka és ügyeleti kötelezettség krónikus osztályra). A létszámproblémák miatt a szakorvosi képzési programok elöírásainak betartása (külső képzőhelyeken töltendő gyakorlatok) sok helyen akadályba ütközik.

Jelentős volt az elmúlt két évtizedben a neurológus szakorvosok külföldre vándorlása. Például 2009-ben huszonkét neurológus kért hivatalos igazolást külföldi munkavállaláshoz, ez a szám megegyezik az évente átlagosan szakvizsgát szerzők számával. Néhány megyében gondot jelent a fiatal szakorvosok hiánya: kilenc megyében (Borsod-Abaúj, Komárom-Esztergom, Somogy, Tolna, Baranya, Békés, Jász-Nagykun-Szolnok, Veszprém, Zala) legföljebb egy harmincöt év alatti neurológus szakorvost tartott nyilván a rendszer 2010-ben. 


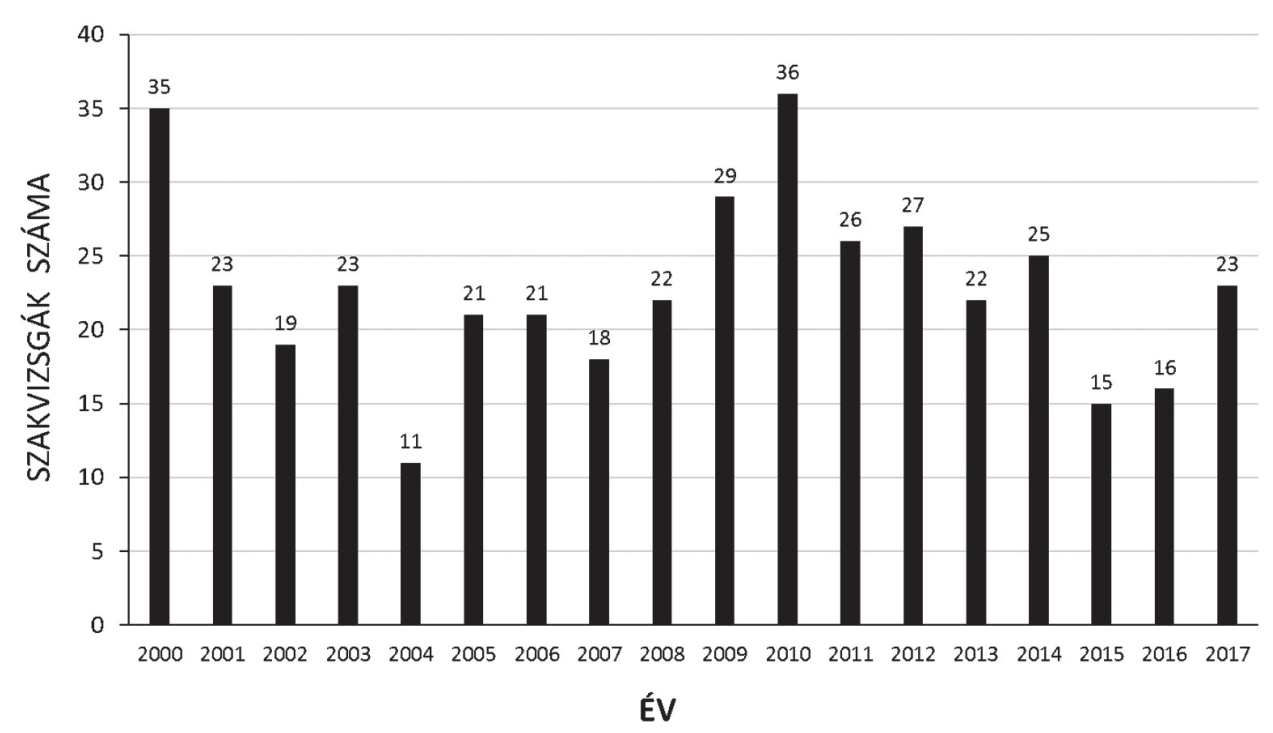

2. ábra. A neurológia szakvizsgát tevők száma Magyarországon 2000-2017 között. Átlag: 23 szakvizsga/év (saját szerkesztés)

A szakorvos utánpótlás helyzetét a négy egyetemi klinika vezetője 2010-ben az Ideggyógyászati Szemle hasábjain foglalta össze (Bereczki et al., 2010). A tíz éve tapasztalt tendenciák alapján 2010-ben prognosztizálható volt 2020-ra a neurológiai szakma jelentös elöregedése, a hatvan év alatti korosztály (különösen a 40-49 évesek) számának és arányának csökkenése, a hatvan fölötti korosztály növekedése még akkor is, ha az elvándorlás megszűnik. A 2009-es felmérést követően 2012-ben újravizsgáltuk a praktizáló neurológusok számát Magyarországon; praktizáló neurológusnak azt tekintettük, aki hetente legalább egy (tehát az év során legalább ötvenkét) esetet vizsgált. Jól látható, hogy 2012-re a negyven év fölötti korcsoportban következetesen csökkent a praktizáló neurológusok száma 2009-hez képest (3. ábra), a 2009 és 2012 közötti három év során összesen 153 (gyakorlatilag hetente egy) praktizáló neurológus szakorvossal lett kevesebb Magyarországon a neurológiai feladatok ellátására. A tapasztalt (41-65 év közötti) generáció létszáma ezen három év alatt 25\%-kal lett kevesebb. A szakorvosképzés elsősorban egyetemi feladat, a 2012 és 2016 közötti öt évben például a Semmelweis Egyetem Neurológiai Klinikáján tizenegy munkatárs szerzett szakvizsgát, közülük később öten külföldön vállaltak munkát. További négy kolléga részállásban vagy GYES-en van, tehát az adott ötéves periódusban képződött tizenegy szakorvos közül 2018-ban mindössze ketten vesznek részt teljes munkaidőben a betegellátásban. 


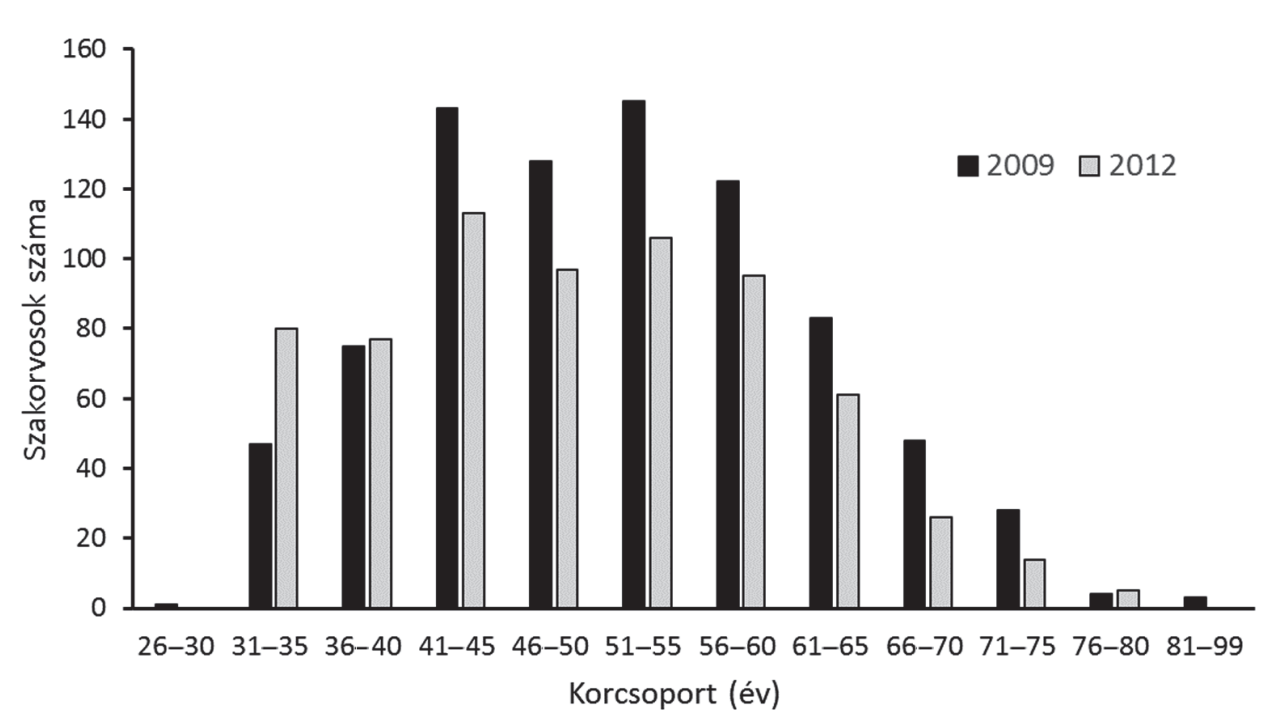

3. ábra. A betegellátásban aktívan részt vevő neurológusok számának változása 2009-2012 között (saját szerkesztés)

\section{A JELENLEGI HELYZET}

A jelenlegi helyzet felmérésére 2017 végén kérdőívet kaptak a klinikák vezetői és néhány kórházi osztály föorvosa, amely kérdőív a szakorvosi ellátottságra, ennek alakulására, az utánpótlás perspektíváira irányult; a rutin terhelésre, például a havi ügyeletek számára, a rezidensek számának alakulására, a tudományos tevékenység lehetőségeire (kutatási feltételek, kutatási területek, PhD-fokozatok), a fejlődő és problémát jelentő részterületekre, a rutin betegellátás, az oktatás és a tudományos munka gátjaira, és a problémamegoldás lehetőségeire. A négy egyetemi klinika vezetőin túl öt kórház neurológiai osztályáról kaptuk vissza a kérdöíveket.

A négy egyetem néhány tudományos jellemzőjét az 1. táblázat foglalja össze. Látható, hogy az egyetemi klinikák aktívak a PhD-képzésben. Minden egyetemi klinikáról nyújtottak be az elmúlt két év során MTA doktori pályázatot is - ebben nagy szerepe volt a Nemzeti Agykutatási Programnak. Különböző kutatói programokban jelenleg több mint ötven, PhD-képzésben részesülő munkatárs vesz részt a négy egyetemi klinikán. A tudományos fokozatot szerzők között a külföldre vándorlás még jelentősebb, mint a szakorvosok között, például a Semmelweis Egyetem Neurológiai Klinika munkatársai közül 2012 és 2016 között nyolcan szereztek PhD-fokozatot, közülük hatan külföldön dolgoznak. Az orvosegyetemek tudományos tevékenységét tekintve jellemző a jelentős volumenü 
PhD-képzés, valamint mind a négy klinikán számottevő az MTA doktori fokozat megszerzése. Az egyetemi klinikákon futnak kutatási pályázatok (Nemzeti Agykutatási Program, MTA-kutatócsoport, GINOP) a legfontosabb kutatási területek a cerebrovaszkuláris, a neuroimmunológia, az idegrendszeri képalkotás, a mozgászavarok, a neuroszonológia, a neurodegeneratív betegségek, a perifériás idegrendszeri kórképek, az epilepszia és a neuroepidemiológia területei. Az ipar részéről érkező megkeresések szakmánk elismerését tükrözik, a betegbevonásban az egyetemi klinikák azonban általában elmaradnak a nagy kórházakhoz viszonyítva.

A jelenlegi helyzet problémáit az egyetemi klinikák a következőkben jelölték meg: nincs elég szakorvos a többszörös feladatok (betegellátás, oktatás, kutatás) ellátásához; az oktatásban nagy a hallgatói létszám; növekvő ambuláns forgalom és ügyeleti szám; elégtelen finanszírozás (homogén betegségcsoportok - HBCS, teljesítmény volumenkorlát - TVK). A HBCS-alapú finanszírozás nem tesz különbséget egy diagnózison belül az enyhébb és a súlyosabb, tehát költségesebb ellátást igénylő betegek finanszírozása között. Ez hátrányosan érinti azokat az ellátóhelyeket, ahol az átlagosnál nagyobb arányban jelennek meg a súlyosabb esetek. A TVK azt jelenti, hogy egy adott hónapban a betegellátás finanszírozásának felső határa van. Mivel a területi betegellátási kötelezettség miatt a betegeket el kell látni, ezért a logikai ellentmondás (az ellátási kötelezettség ellenére felső korláttal behatárolt finanszírozás) két módon oldható fel: vagy finanszírozás nélkül látják el a betegek egy részét, vagy egyre hosszabbra nyúlik az előjegyzési idő. A második megoldás sürgős ellátás szükségessége esetén természetesen nem jöhet szóba.

A kórházi neurológiai osztályokról jelzett problémák: nincs kellő érdeklődés a szakma iránt, ezért kevés rezidens jelentkezik; elégtelen részvétel az egyetemi graduális képzési programokban; sok ügyelet; nagy az egy orvosra jutó ellátandó betegszám; a rutin túlterhelés kiégéshez vezet; néhol gond a laboratóriumi és képalkotó (leginkább az MRI) vizsgálatokhoz való hozzáférés; elégtelen finanszírozás (HBCS, TVK); a szakképzési program teljesítése miatt a rezidensek sokat vannak távol; az alacsony díjazás is a távozás irányába hajt; csökkenő létszám; a szakemberhiány a minőségi munka gátja.

A felmérésünk alapján a kórházakra jellemző rutin igénybevétel mellett és a kis létszám miatt helyben nincs idő jelentős volumenủ tudományos kutatásra. A rutin terhelés miatti kiégés a fiatalokban is a tudományos érdeklödés viszszaeséséhez vezet. Anyagi okok miatt sok helyen a helyi könyvtárak leépítésére került sor. A hazai kongresszusi prezentációkon túl nagyobb tudományos teljesítményekre a kórházak munkatársai közül csak elvétve van példa. A kórházak is aktívan részt vesznek gyógyszeripari kutatásokban. A kórházi főorvosok lehetséges opciónak tartják az egyetemekkel történő kooperálást a tudományos tevékenység fejlesztésére. 
1. táblázat. A négy egyetemi klinika humán erőforrás jellemzői a tudományos kutatás néhány szempontja alapján

\begin{tabular}{|c|c|c|c|c|}
\hline $\begin{array}{c}\text { Kérdés a Neurológiai Klinikára } \\
\text { vonatkozóan }\end{array}$ & $\begin{array}{l}\text { Debreceni } \\
\text { Egyetem }\end{array}$ & $\begin{array}{l}\text { Pécsi } \\
\text { Tudomány- } \\
\text { egyetem }\end{array}$ & $\begin{array}{l}\text { Szegedi } \\
\text { Tudomány- } \\
\text { egyetem }\end{array}$ & $\begin{array}{l}\text { Semmelweis } \\
\text { Egyetem }\end{array}$ \\
\hline $\begin{array}{l}\text { PhD-fokozatszerzések az elmúlt öt } \\
\text { évben }\end{array}$ & 6 & $11^{\mathrm{a}}$ & 17 & 8 \\
\hline $\begin{array}{l}\text { Jelenleg PhD-képzésben részt vevő } \\
\text { munkatársak }\end{array}$ & 6 & 8 & $30 *$ & 8 \\
\hline $\begin{array}{l}\text { PhD-fokozattal rendelkezők (de MTA } \\
\text { doktori fokozattal nem rendelkezők) }\end{array}$ & 10 & $18^{\mathrm{a}}$ & $27 * *$ & 12 \\
\hline $\begin{array}{l}\text { Az elmúlt öt évben a klinikáról } \\
\text { külföldre távozó, PhD-fokozattal } \\
\text { rendelkezök száma }\end{array}$ & 1 & 0 & 4 & 6 \\
\hline $\begin{array}{l}\text { Az elmúlt tíz év során MTA doktori } \\
\text { fokozatszerzések }\end{array}$ & 1 & 3 & 3 & 2 \\
\hline $\begin{array}{l}\text { MTA doktori fokozattal rendelkező } \\
\text { aktív munkatársak }\end{array}$ & 2 & 3 & 4 & 2 \\
\hline $\begin{array}{l}\text { MTA doktori fokozattal rendelkező } \\
\text { emeritusok és nyugdíjas munkatársak }\end{array}$ & 1 & 0 & 0 & 2 \\
\hline $\begin{array}{l}\text { Az egyetem körzetébe tartozó } \\
\text { intézményekben dolgozó, MTA doktori } \\
\text { fokozattal rendelkező neurológusok }\end{array}$ & 0 & 0 & 0 & 3 \\
\hline
\end{tabular}

Megjegyzés: aEbből három tisztán kutatói státuson (tehát nem klinikusok), *15 fő kutatói programban + 15 fö klinikai feladat mellett, **21 fö klinikai álláson +6 kutató

\section{A JÖVŐ LEHETŐSÉGEI}

A megoldás lehetőségeit, illetve lépéseit az egyetemek a következőkben foglalták össze: jelentős díjazásnövelés lesz szükséges; differenciálni kellene a hiányszakmák és a geográfiai helyzet alapján is, valamint szakmán belül feladatarányosan (például első vagy harmadik progresszivitási szintủ betegellátás); a jelenleg jelentősen eltérő ügyeleti dijak feladatarányos emelése szükséges országosan egységesen. Segíthetne szolgálati lakás, illetve részmunkaidős pozíciók lehetősége. A hármas követelményrendszer (betegellátás, oktatás, kutatás) megjelenítését a teljes munkaidőn belül deklarálni szükséges, tehát legyen világos és egyértelmü, hogy a teljes munkaidőn belül milyen arányban gyógyít, oktat és kutat a klinikai orvos, és ezt „full-time equivalent” (FTE) egységben egyénre szabottan nevezzék 
is meg a munkaköri leírásokban. A müszerezettség javítása; a betegellátás finanszírozásának rendezése (mind a járó-, mind a fekvőbeteg-ellátásban); a szakdolgozói utánpótlás stabilizálása; ápolási osztályok kialakítása javíthatna a jelenlegi helyzeten.

A kórházi osztályok részéről megfogalmazott megoldási javaslatok: fizetésrendezés; szolgálati lakás; az orvoslétszám emelése; a munkakörülmények javítása; a szakmai feltételek javítása (például műszerbeszerzések); egyetemi munkacsoportokhoz történő csatlakozás a tudományos munka iránt érdeklődők számára; a finanszírozás hozzáigazítása a fejlődéshez; a rezidensképzési rendszer korrekciója, a realitásokhoz történő igazítása.

A négy orvosegyetemi klinika igazgatói 2011-ben írásos javaslatot tettek a magyarországi neurológiai életpályamodellre 2020-ig (Bereczki et al., 2011). A neurológiai szakorvosi életpályamodell fontos részének javasoltuk a szakellátásban a háziorvosi rendszerben már évek óta jól müködő, ahhoz hasonló közfinanszírozott magánorvosi szakellátás bevezetését. Megfelelő finanszírozás mellett egy ilyen lehetőség a szakorvosok számára egyrészt szakmai önállóságot, másrészt olyan anyagi környezetet teremthetne, mely vonzóvá tenné a neurológiai szakterület választását és annak Magyarországon történő gyakorlását. Egy ilyen változás feltehetően kedvezően hatna a neurológia terén folytatott tudományos tevékenységre is.

\section{KÖSZÖNETNYILVÁNÍTÁS}

A 2017-es felmérésben való közreműködésért köszönet illeti a következő klinikaigazgató egyetemi tanárokat és osztályvezető főorvosokat: Csiba László, Oláh László (Debreceni Egyetem, Neurológiai Klinika), Janszky József (Pécsi Tudományegyetem Neurológiai Klinika), Vécsei László (Szegedi Tudományegyetem Neurológiai Klinika), Kerényi Levente (Fejér Megyei Kórház Neurológiai Osztály), Nikl János (Zala Megyei Kórház Neurológiai Osztály), Németh László (Kanizsai Dorottya Kórház Neurológiai Osztály), Diószeghy Péter (Szabolcs-Szatmár-Bereg Megyei Kórház Neurológiai Osztály), Valikovics Attila (Borsod-Abaúj-Zemplén Megyei Kórház Neurológiai Osztály).

IRODALOM

Bereczki D. - Ajtay A. (2011): Neurológia 2009: helyzetfelmérés a magyarországi neurológiai kapacitásokról, azok kihasználtságáról és a szakorvosokról a 2009-es intézményi jelentések alapján. Ideggyógyászati Szemle, 64, 173-185. https://lib.semmelweis.hu/sepub/pdf/2011/ a21692275 
Bereczki D. - Ajtay A. (szerk.) (2012): Magyarország neurológiai ellátása-2012. Budapest: Neurológiai Szakmai Kollégium, 3-469.

Bereczki, D. - Csiba L. - Komoly S. et al. (2010): Veszélyben a jövő - a neurológusszakorvos-képzés és szakorvos-utánpótlás helyzetének áttekintése - 2010. Ideggyógyászati Szemle, 63, 259265. http://publicatio.bibl.u-szeged.hu/9922/1/Bereczki_Veszelyben_a_jovo_u.pdf

Bereczki D. - Csiba L. - Komoly S. et al. (2011): A neurológia magyarországi (élet)pályamodellje - megoldási javaslat 2020-ig. Ideggyógyászati Szemle, 64, 377-384. https://lib.semmelweis. $\mathrm{hu} / \mathrm{sepub} / \mathrm{pdf} / 2011 / \mathrm{a} 85$

Majláth Z. - Ajtay A. - Bereczki D. et al. (2013): Neurology in Hungary-Past, Present and Future. Neurology, 80, 1518-1520. DOI: 10.1212/WNL.0b013e31828cf7c3, https://n.neurology.org/ content/80/16/1518.long

Oberfrank F. - Ajtay A. - Bereczki D. (2018): Demand for Neurological Services in Central-Eastern Europe: A 10-year National Survey in Hungary. European Journal of Neurology, 25, 984 990. DOI: 10.1111/ene.13645 